\section{Prevalence of sickle cell trait in blood donors: A systematic review}

\author{
Letícia A. F. Machado, ${ }^{1}$ Edney G. da C. Gomes, ${ }^{1}$ Lívia C. de Oliveira, ${ }^{2 *}$ Larissa C. Lima, ${ }^{2}$ José F. N. Neto ${ }^{3}$
}

\begin{abstract}
Introduction: The sickle cell trait is a genetic mutation characterized by the presence of hemoglobin S (HbS) in heterozygosis in which patients are asymptomatic, which makes them suitable for blood donation. Aim: Systematizing data related to the prevalence of the sickle cell trait among blood donors. Materials and methods: A search of the literature was conducted in May 2019 to seek articles published from 1990 and which had available online abstracts, in four electronic databases. Studies were selected with the following characteristics: (1) original work; (2) observational; (3) developed with blood donors; and (4) showing prevalence of sickle cell trait. Two independent reviewers identified the articles for inclusion in this systematic review of the literature (SRL), extracted the pre-determined data and carried out the evaluation of the works' methodological quality. Results: Eight studies published in the last 12 years in different countries were selected to take part in this SRL. With variable sample size, all presented a cross-sectional methodology. For the detection of the presence of HbS, electrophoresis in alkaline $\mathrm{pH}$ was commonly used. The statistical analysis developed involved simple techniques, showing that the prevalence of blood donors with sickle cell trait ranged from $0.4 \%$ to $20.8 \%$. The majority of studies was considered of high methodological quality. Conclusion: The prevalence of sickle cell trait among blood donors varies widely, although it may not be moderate, given that the screening of $\mathrm{HbS}$ has important clinical significance for the proper use of this blood component.
\end{abstract}

Keywords: Sickle cell trait; Blood donor; Blood transfusion.

\section{Resumo}

Prevalência de traço falciforme em doadores de sangue: Uma revisão sistemática

Introdução O traço falciforme é uma mutação genética caracterizada pela presença de hemoglobina $\mathrm{S}(\mathrm{HbS})$ na heterozigose em que os pacientes são assintomáticos, o que os torna adequados para doação de sangue. Objetivo: Sistematizar dados relacionados à prevalência do traço falciforme entre doadores de sangue. Materiais e métodos: Uma pesquisa bibliográfica foi realizada em maio de 2019 para busca de artigos publicados a partir de 1990 e que dispunham de resumo on-line, em quatro bases de dados eletrônicas. Os estudos foram selecionados com as seguintes características: (1) trabalho original; (2) observacional; (3) desenvolvido com doadores de sangue; (4) ter prevalência de traço falciforme. Dois revisores independentes identificaram os artigos para inclusão nesta revisão sistemática
1. Professional Master's in Health. Medicine Laboratory and Forensic Technology. Rio de Janeiro State University. Rio de Janeiro, RJ, Brazil

2. Search Group NutriPali. Nutritionist Palliative Care Unit, National Cancer Institute José Alencar Gomes da Silva (INCA). Rio de Janeiro, RJ, Brazil.

3. Lipids Laboratory-LabLip, Faculty of Medical Sciences. Rio de Janeiro State University. Rio de Janeiro, RJ, Brazil.

\section{*Correspondence address:}

Visconde de Santa Isabel Street, 274,

Rio de Janeiro, RJ, Brazil.

ZIP 20560-120

E-mail: lillycostaoliveira@gmail.com

BJHBS, Rio de Janeiro, 2019;18(2):95-102

Received on 05/31/2019. Approved on 07/05/2019.

da literatura (SRL), extraíram os dados pré-determinados e realizaram a avaliação da qualidade metodológica das obras. Resultados: Oito estudos publicados nos últimos 12 anos em diferentes países, foram selecionados para participar desta SRL. Com tamanho de amostra variável, todos tinham um tipo de corte transversal. Para a detecção da presença de HbS, foi comum o uso de eletroforese em $\mathrm{pH}$ alcalino. As análises estatísticas desenvolvidas envolveram técnicas simples, mostrando que a prevalência de doadores de sangue com traço falciforme variou de $0,4 \%$ a 20,8\%. A maioria dos estudos foi considerada de alta qualidade metodológica. Conclusão: A prevalência do traço falciforme entre doadores de sangue é altamente variável, porém pode não ser moderada, uma vez que o rastreamento da $\mathrm{HbS}$ tem grande significado clínico para o uso adequado do hemocomponente.

Descritores: Traço falciforme; Doador de sangue; Transfusão de sangue.

\section{Resumen}

Prevalencia del rasgo de células falciformes en los donantes de sangre: Una revisión sistemática

iIntroducción: El rasgo de células falciformes es una mutación genética caracterizada por la presencia de hemoglobina $\mathrm{S}(\mathrm{HbS})$ en la heterocigosis en la que los pacientes son 
asintomáticos, lo que los hace adecuados para la donación de sangre. Objetivo: Sistematizar los datos relacionados con la prevalencia del rasgo de células falciformes entre los donantes de sangre. Material y Métodos: En mayo de 2019 se realizó una búsqueda bibliográfica para buscar artículos publicados desde 1990 y que tenían un resumen en línea disponible, en cuatro bases de datos electrónicas. Los estudios se seleccionaron con las siguientes características: (1) trabajo original; (2) observacional; (3) desarrollado con donantes de sangre; (4) con prevalencia de rasgo de células falciformes. Dos revisores independientes identificaron los artículos para su inclusión en esta revisión sistemática de la literatura (RSL), extrajeron los datos predeterminados y llevaron a cabo la evaluación de la calidad metodológica de los trabajos. Resultados: Se seleccionaron ocho estudios publicados en los últimos 12 años en diferentes países para participar en esta RSL. Con el tamaño variable de la muestra, todos tenían un tipo de sección transversal. Para la detección de la presencia de HbS, era común utilizar electroforesis en pH alcalino. Los análisis estadísticos desarrollados involucraron técnicas simples, que mostraron que la prevalencia de donantes de sangre con rasgo de células falciformes varió de $0.4 \%$ a $20.8 \%$. La mayoría de los estudios fueron considerados de alta calidad metodológica. Conclusión: La prevalencia del rasgo de células falciformes entre los donantes de sangre es muy variable, sin embargo, puede no ser moderada, dado que la detección de $\mathrm{HbS}$ tiene una gran importancia clínica para el uso adecuado del componente sanguíneo.

Palabras clave: Rasgo de células falciformes; Donador de sangre; Transfusión de sangre.

\section{Introduction}

Sickle cell disease is the term used to designate the genetic alteration modifying the nitrogen base of the deoxyribonucleic acid (DNA) that composes the gene responsible for synthesizing the beta-globin gene of hemoglobin. In individuals with sickle cell disease, this mutation results in the formation of hemoglobin $\mathrm{S}(\mathrm{HbS}){ }^{1-3}$

Different genotypes can be found in individuals with sickle cell disease. Those homozygous for the gene of the HbS present the form called sickle cell anemia. Other genetic abnormalities associated with hemoglobin may also occur in combination with the $\mathrm{HbS}$, and are collectively called sickle cell disease. ${ }^{4}$ The sickle cell trait, in turn, is characterized by the presentation of $\mathrm{HbS}$ in heterozygosis in isolation. The latter is defined as a clinically benign condition in which the individual is the bearer of the $\mathrm{HbS}$ but presents no vaso-occlusive symptoms under physiological conditions. Its prevalence varies considerably in the different regions of the globe, being greater in countries of Equatorial Africa, Saudi Arabia, India, Turkey, Greece and Italy. ${ }^{5}$

The identification of carriers of the sickle cell trait, although not offering any immediate benefit to newborns, enables the identification of couples with risk of generating a child with sickle cell disease, since individuals who inherit thegene for $\mathrm{HbS}$ from both father and the mother are clinically ill. ${ }^{5}$

The ignorance of portability of HbS by individuals with sickle cell trait, associated with the absence of symptoms, makes them suitable for blood donation. ${ }^{67} 7$ However, the blood from individuals with hemoglobin

disorders requires an inherent direction, because it cannot beleucocyte-depleted and cannot be used in patients with hemoglobinopathies, with severe acidosis in newborns or intrauterine transfusion. ${ }^{8,9}$

Therefore, this systematic review of the literature (SRL) aims to systematize the results of observational studies that assessed the prevalence of sickle cell trait in blood donors, with the aim of contributing to the dissemination of information on this public health problem.

\section{Methods}

\section{Search strategy}

The study is a SLR performed according to the guidelines of Preferred Reporting Items for Systematic Reviews and Meta-Analyses Group Guidelines (PRISMA). ${ }^{10}$

In the month of May 2019, a single researcher (L.C.L.) carried out a literature search in electronic databases Cochrane Systematic Reviews (CDSR), Latin American and Caribbean Literature in Health Sciences (LILACS) Capes Journals and US National Library of Medicine, National Institutes of Health (Pubmed) and Scopus, using the keywords sickle cell trait, blood donors and blood transfusion. Although the research is defined by searching through these databases, the Snowballing method was used as a second strategy, with the aim of identifying the greatest number of potential studies. All the references identified were recorded and organized in a spreadsheet. 
The articles needed to have been published since 1990 and have an online abstract available. The search in the databases was followed by independent reading of the titles and abstracts of papers by two authors (L.A.F.M. and L.C.O.).

As inclusion criteria, the articles should be: (1) original work; (2) observational; (3) developed with blood donors; and (4) show prevalence of sickle cell trait. No restrictions were made regarding language.

After this step, the works that met or appeared to meet the inclusion criteria were selected for a reading of the entire text, by the same reviewers, in order to decide on the inclusion or not in this SLR. Disagreements among the reviewers were resolved by consensus and, when necessary, by consulting a third author (J.F.A.N.).

\section{Data extraction}

The data items extracted from the articles for the construction of tables were: (a) place where the studies were performed; (b) age of participants; (c) experimental; (d) sample size; (e) objectives; (f) methodology used for determination of the HbS; ( $g$ ) statistical analysis; (h) other variables used; and (i) main results. One author (L.A.F.M.) performed this activity, using his or her own form. Another author (L.C.O.) reviewed the implementation of the same. Discrepancies in data were resolved by consensus.

\section{Evaluation of the methodological quality}

The selected studies were independently analyzed by two authors (E.G.C.G. and L.C.O.), as to methodological quality by use of the Joanna Briggs Institute Prevalence Critical Appraisal Tool. This is a tool for the evaluation of cross-sectional studies composed of nine items. The works were classified according to the number of items handled: high quality from 7 to 9 items; moderate quality from 4 to 6 items; and low quality $<3$ items fulfilled. ${ }^{11}$

The kappa coefficient $(\mathrm{k})$ was used to evaluate the concordance between the two authors (E.G.C.G. and L.C.O.). Discordant cases were resolved by consensus or the consultation of the opinion of the third author (J.F.N.N.).

\section{Results}

The process of selecting articles for systematic review is shown in Figure 1. This process enabled the identification of 83 articles in PubMed, 221 in Scopus and 115 in Lilacs. The studies were excluded mainly by reading the titles and abstracts, whose reasons are listed in the illustration. In addition, examination of the lists of references of articles did not identify any other suitable publication. Eight studies were selected.,12-18

The articles were published during the last 12 years, with varying sample sizes, involving adult blood donors from different countries. ${ }^{7,14,16,18}$ For the detection of the presence of $\mathrm{HbS}$, electrophoresis in alkaline $\mathrm{pH}$ was commonly used (Table 1 ).

Simple statistical analyses were employed, showing that the prevalence of sickle cell trait in blood donors ranged from $0.4 \%$ in São Paulo/Brazil ${ }^{14}$ to $20.8 \%$ in Curitiba/Brazil ${ }^{17}$. There was variability among the other variables used in the analysis of the data, and sex, age, race and association with other genetic abnormalities were the most commonly used (Table 2). Under this focus, Lidani et al. ${ }^{17}$ and Martins et al. ${ }^{12}$ demonstrated a higher prevalence of sickle cell trait among afrodescendant individuals. In addition, according to Adu et al., ${ }^{18}$ having a mild deficiency of glucose-6-phosphate dehydrogenase (G6PD) is associated with an increased risk of having sickle cell trait. In the studies of Egesie et al. ${ }^{16}$ and Alabdulaali et al., ${ }^{14}$ part of the population evaluated presented an association between these two conditions. Having mild deficiency of G6PD or showing trace of HbS were variables that were not associated with the circulation levels of hemoglobin of the donor. ${ }^{18}$

The majority of studies was considered to be of high methodological quality, although only one received the maximum score (Table 2). The factors for which, with greater frequency, the articles did not score higher, was the relative size of the sample, the representativeness of the sample and statistical analysis. The initial agreement between the two authors about the scores given to the work was considered substantial $(\mathrm{k}=0.89)$ (data not shown in tables).

\section{Discussion}

The scientific literature has few studies about the prevalence of sickle cell trait in blood donors., ${ }^{72-18}$ However, a cross-sectional design, ${ }^{19}$ appropriate to the proposed objectives of the majority of studies that have already done, presented a simple methodology and of high quality.

As noted above, the prevalence of sickle cell trait among blood donors presented variable values. The differences found in prevalence may be related 


\section{Original article}

Potentially relevant studies identified by keywords for reading titles in

Pubmed $(n=83)$; Scopus $(n=221)$ and Lilacs $(n=115)$

$$
\mathbf{N}=\mathbf{4 1 9}
$$

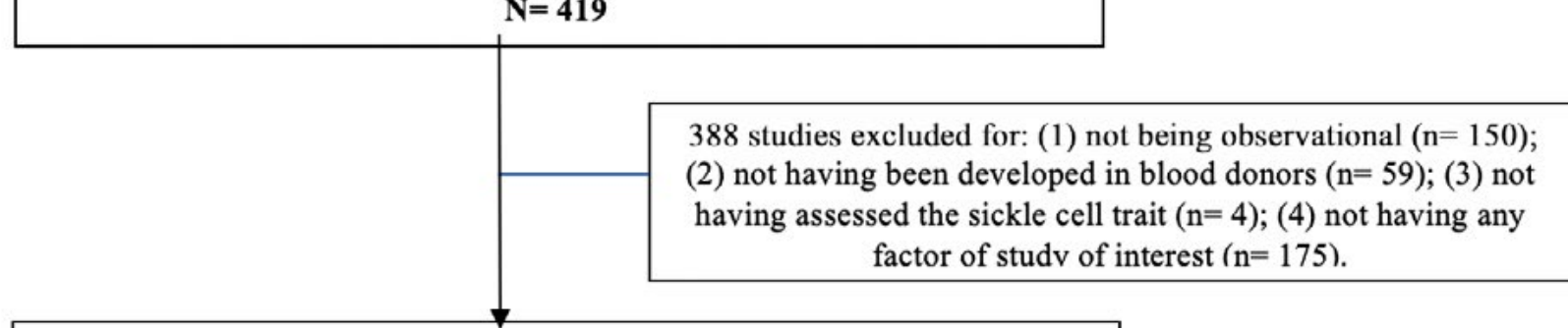

Original publications selected for reading the abstracts on Pubmed $(n=15)$;

$$
\text { Scopus }(n=10) \text { and Lilacs }(n=6)
$$

$\mathbf{N}=\mathbf{3 1}$

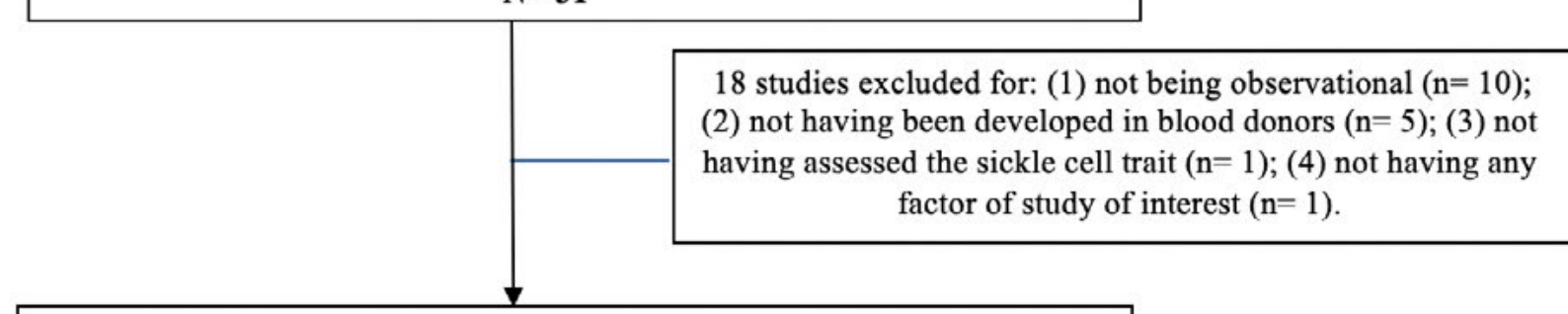

Studies selected for reading the full text in Pubmed $(n=4)$; Scopus $(n=6)$ and

Lilacs $(n=4)$

$\mathbf{N}=14$

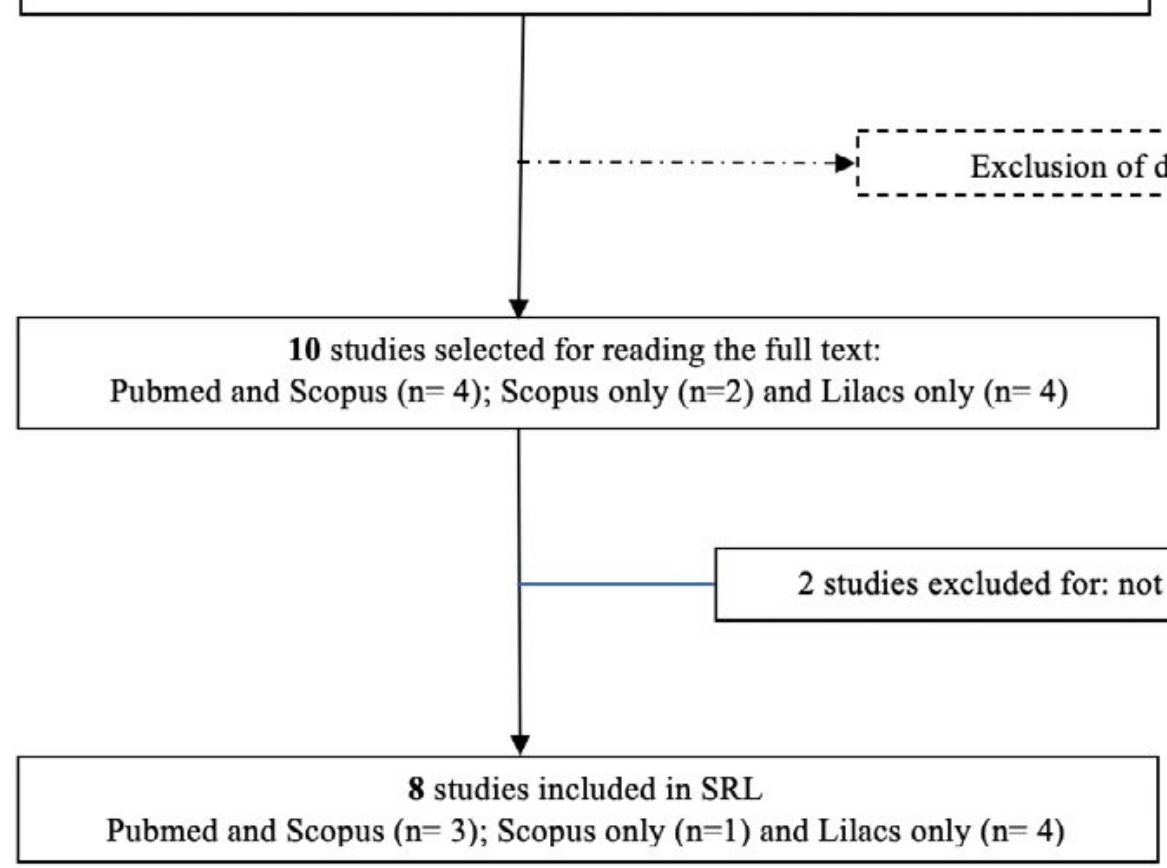

Figure 1. Flowchart of the selection of papers*

Note: $n=$ number of observations; SRL= systematic review of the literature.

*Designed in accordance with the proposal of the Group Prism, 2009. 
Letícia A. F. Machado e cols. • Prevalence of sickle cell trait in blood donors

Table 1. Description of studies as to the authors, year of publication, origin, age of participants, study design, sample size and methods of HbS determination

\begin{tabular}{|c|c|c|c|c|c|c|c|}
\hline ID & Author, year & Origin & Age (year) & Design & $\mathrm{N}$ & Goal & $\mathrm{HbS}$ dosage \\
\hline 1 & $\begin{array}{c}\text { Adu et al., } \\
2016\end{array}$ & Ghana & $18-9$ & $\begin{array}{c}\text { Cross } \\
\text { sectional }\end{array}$ & 200 & $\begin{array}{l}\text { To evaluate the prevalence } \\
\text { of G6PD deficiency and the } \\
\text { HbS characteristic among } \\
\text { the blood donors. }\end{array}$ & $\begin{array}{l}\text { Electrophoresis of } \\
\text { cellulose acetate } \\
(\mathrm{pH} \mathrm{8.6)}\end{array}$ \\
\hline 2 & $\begin{array}{l}\text { Vivas et al., } \\
2006\end{array}$ & Brazil & $\mathrm{NI}$ & $\begin{array}{c}\text { Cross } \\
\text { sectional }\end{array}$ & 1345 & $\begin{array}{l}\text { To identify healthy } \\
\text { gene carriers for } \\
\text { hemoglobinopathies } \\
\text { among blood donors. }\end{array}$ & $\begin{array}{l}\text { Alkaline } \\
\text { Electrophoresis } \\
\text { (pH 8.6); } \\
\text { Sickling test; } \\
\text { Solubility test; } \\
\text { HPLC. }\end{array}$ \\
\hline
\end{tabular}

\begin{tabular}{|c|c|c|c|c|c|c|c|}
\hline 3 & $\begin{array}{l}\text { Antwi-Baffour } \\
\text { et al., } 2015\end{array}$ & Ghana & $17-60$ & $\begin{array}{c}\text { Cross } \\
\text { sectional }\end{array}$ & 150 & $\begin{array}{l}\text { To determine the } \\
\text { prevalence of the } \mathrm{HbS} \\
\text { characteristic among } \\
\text { blood donors. }\end{array}$ & $\begin{array}{l}\text { Alkaline } \\
\text { electrophoresis; } \\
\text { Sickling test. }\end{array}$ \\
\hline 4 & $\begin{array}{l}\text { Lidani et al., } \\
\quad 2015\end{array}$ & Brazil & $\mathrm{NI}$ & $\begin{array}{c}\text { Cross } \\
\text { sectional }\end{array}$ & 83213 & $\begin{array}{l}\text { To determine the } \\
\text { prevalence of } \mathrm{HbS} \text { among } \\
\text { individuals of Asian, Afro } \\
\text { and Euro-brazilian origin, in } \\
\text { a blood bank of Curitiba. }\end{array}$ & $\begin{array}{l}\text { Alkaline } \\
\text { electrophoresis; } \\
\text { Test of solubility. }\end{array}$ \\
\hline 5 & $\begin{array}{c}\text { Egesie et al., } \\
2013\end{array}$ & Nigeria & $20-49$ & $\begin{array}{c}\text { Cross } \\
\text { sectional }\end{array}$ & 130 & $\begin{array}{l}\text { To determine the } \\
\text { prevalence of G6PD } \\
\text { deficiency and the } \\
\text { characteristic HbS among } \\
\text { blood donors and the risks } \\
\text { of transfusion of blood. }\end{array}$ & $\begin{array}{l}\text { Electrophoresis of } \\
\text { cellulose acetate } \\
\text { (pH 8.9) }\end{array}$ \\
\hline 6 & $\begin{array}{l}\text { Alabdulaali et } \\
\text { al., } 2010\end{array}$ & Saudi Arabia & $18-50$ & $\begin{array}{c}\text { Cross } \\
\text { sectional }\end{array}$ & 1150 & $\begin{array}{l}\text { To evaluate the prevalence } \\
\text { of G6PD deficiency and the } \\
\text { HbS characteristic among } \\
\text { blood donors. }\end{array}$ & $\begin{array}{l}\text { Solubility test; } \\
\text { alkaline } \\
\text { electrophoresis. }\end{array}$ \\
\hline 7 & $\begin{array}{c}\text { Moraes \& } \\
\text { Galioti, } 2010\end{array}$ & Brazil & $\mathrm{NI}$ & $\begin{array}{c}\text { Cross } \\
\text { sectional }\end{array}$ & 93604 & $\begin{array}{l}\text { To evaluate the presence of } \\
\text { sickle cell trait in São José } \\
\text { dos Campos, correlating } \\
\text { with the history of the local } \\
\text { population. }\end{array}$ & $\begin{array}{l}\text { Electrophoresis } \\
(\mathrm{pH} \mathrm{8.6)}\end{array}$ \\
\hline 8 & $\begin{array}{l}\text { Martins et al., } \\
2005\end{array}$ & Brazil & $\mathrm{NI}$ & $\begin{array}{c}\text { Cross } \\
\text { sectional }\end{array}$ & 70263 & $\begin{array}{l}\text { To evaluate the frequency } \\
\text { of } \mathrm{HbS} \text { in blood donors. }\end{array}$ & $\begin{array}{l}\text { Electrophoresis; } \\
\text { Sickling test; } \\
\text { Solubility test. }\end{array}$ \\
\hline
\end{tabular}

Legend: $\mathrm{N}=$ sample size; $\mathrm{NI}=$ not informed; G6PD= glucose-6-phosphate dehydrogenase; HbS= hemoglobin S; HPLC= High Performance Liquid Chromatography. 


\section{Original article}

Table 2. Description of studies regarding the statistical tests, prevalence of sickle cell trait, other variables, main results and methodological quality

\begin{tabular}{|c|c|c|c|c|c|}
\hline ID & $\begin{array}{l}\text { Statistical } \\
\text { tests }\end{array}$ & $\begin{array}{l}\text { Prevalence } \\
\text { of sickle } \\
\text { cell trait }\end{array}$ & $\begin{array}{l}\text { Other } \\
\text { variables }\end{array}$ & Main results & $\begin{array}{l}\text { Methodological } \\
\text { quality* }\end{array}$ \\
\hline 1 & $\begin{array}{l}\text { Pearson } \\
\text { test; } \\
\text { Kruskal- } \\
\text { Wallis test; } \\
\text { Logistic } \\
\text { regression. }\end{array}$ & $39(7 \%)$ & $\begin{array}{l}\text { Age; Sex; } \\
\text { G6PD } \\
\text { deficiency; } \\
\text { type of donor. }\end{array}$ & $\begin{array}{l}\text { Have mild deficiency of G6PD (OR: } 2.4 ; \mathrm{Cl}: 1.0-5.5 \text { ), being } \\
\text { remunerated blood donors (OR: } 5.6 ; \mathrm{Cl}: 1.3-24.0 \text { ) or volunteer } \\
\text { s(OR: } 2.4 ; \mathrm{Cl}: 1.1-5.4 \text { ) was associated with a higher risk of having } \\
\text { sickle cell trait. Screening for hemoglobinopathies should be } \\
\text { incorporated in blood donation protocols. }\end{array}$ & $\begin{array}{l}7 \text { points } \\
\text { High quality }\end{array}$ \\
\hline 2 & $\begin{array}{l}\text { Fisher test; } \\
\chi 2\end{array}$ & $55(4 \%)$ & $\begin{array}{l}\mathrm{Hm} ; \mathrm{Hb} ; \mathrm{HTC} \\
\mathrm{HCM} ; \mathrm{VCM} \\
\text { CHCM. }\end{array}$ & $\begin{array}{l}76 \text { samples were identified with abnormal hemoglobins }(5.6 \%) \text {, } \\
\text { of which } 55(4.1 \%) \text { with } \mathrm{Hb}, 19(1.4 \%) \text { with } \mathrm{Hb} A C \text {, one with } \mathrm{Hb} \\
A D \text { and other suggestive of beta-thalassemia. }\end{array}$ & $\begin{array}{l}8 \text { points } \\
\text { High quality }\end{array}$ \\
\hline 3 & $x^{2}$ & 17 (11.3\%) & $\begin{array}{l}\text { Sex; sickle } \\
\text { cell status; } \\
\text { genotype } \\
\text { Hb; prior } \\
\text { donation. }\end{array}$ & $\begin{array}{l}\text { The largest part of the } s 9 \text { ample }(88.7 \%) \text { presented no sickle cell } \\
\text { disease (genotype: } 131=\text { AA e } 2=A C) \text {. All donors' sickle cell traits } \\
\text { had the genotypes AS. }\end{array}$ & $\begin{array}{l}7 \text { points } \\
\text { High quality }\end{array}$ \\
\hline 4 & $\mathrm{NI}$ & 747 (0.9\%) & Sex; race. & $\begin{array}{l}\text { There was a statistically significant positive association for the } \\
\text { sickle cell trait in those of African descent (OR: } 4.0 \text {; IC } 95 \% \text { : } \\
\text { 3.4-4.7), which corroborates data published in other Brazilian } \\
\text { regions and states. }\end{array}$ & $\begin{array}{l}8 \text { points } \\
\text { High quality }\end{array}$ \\
\hline 5 & $\mathrm{NI}$ & 27 (20.8\%) & $\begin{array}{l}\text { Sex, age, type } \\
\text { of } \mathrm{Hb} \text {; G6PD } \\
\text { deficiency. }\end{array}$ & $\begin{array}{l}\text { Of the donors with sickle cell trait, } 26 \text { ( } 20 \%) \text { had G6PD deficiency } \\
\text { and } 7(5.4 \%) \text { had both conditions. Screening for detection } \\
\text { of these characteristics and appropriate use of this blood is } \\
\text { recommended. }\end{array}$ & $\begin{array}{l}6 \text { points } \\
\text { Moderate } \\
\text { Quality }\end{array}$ \\
\hline 6 & $\mathrm{NI}$ & $27(2.3 \%)$ & $\begin{array}{l}\text { Sex; G6PD } \\
\text { deficiency; } \\
\text { Hb; HTC; } \\
\text { HCM; VCM; } \\
\text { Mchc. }\end{array}$ & $\begin{array}{l}\text { Among the donors, } 23(2 \%) \text { were diagnosed with sickle cell trait, } \\
9(0.8 \%) \text { had G6PD deficiency and } 4(0.4 \%) \text { had both conditions. }\end{array}$ & $\begin{array}{l}7 \text { points } \\
\text { High quality }\end{array}$ \\
\hline 7 & $\mathrm{NI}$ & $400(0.4 \%)$ & $\begin{array}{l}\text { Race; allelic } \\
\text { frequency of } \\
\mathrm{HbA} \text { and } \mathrm{HbS} \text {; } \\
\text { region of } \\
\text { origin. }\end{array}$ & $\begin{array}{l}\text { In São José dos Campos, it was found that the index of donors } \\
\text { with sickle cell trait differed from national indices, basing } \\
\text { themselves in local history. }\end{array}$ & $\begin{array}{l}7 \text { points } \\
\text { High quality }\end{array}$ \\
\hline 8 & $\begin{array}{l}\text { Z test; } \\
\chi 2 ; \\
\text { Fisher test; } \\
\text { Analysis of } \\
\text { variance. }\end{array}$ & 696 (0.9\%) & $\begin{array}{l}\text { Sex; race; } \\
\text { age. }\end{array}$ & $\begin{array}{l}\text { The black race presented a higher prevalence than white and } \\
\text { mixed races. The prevalence in females was } 11.41 / 1000 \text { and, } \\
\text { in the males, } 9.44 / 1000 \text {. The largest percentage of } \mathrm{HbS} \text { was } \\
\text { between } 18 \text { and } 29 \text { years of age ( } 52.7 \% \text { ). Knowing who are } \\
\text { the bearers of } \mathrm{HbS} \text { is important, in order to target genetic } \\
\text { counseling. }\end{array}$ & $\begin{array}{l}9 \text { points } \\
\text { High quality }\end{array}$ \\
\hline
\end{tabular}

Legend: $\mathrm{ANOVA}=$ unidirectional analyzes of variance; $\chi 2=$ squared; $\mathrm{Hb}=$ hemoglobin; $\mathrm{Hm}=$ number of erythrocytes; $\mathrm{HCM}=$ hematocrit; $\mathrm{VCM}=$ mean corpuscular volume; $\mathrm{CHCM}=$ mean corpuscular hemoglobin concentration; $\mathrm{G} 6 \mathrm{PD}=$ glucose-6-phosphate dehydrogenase; $\mathrm{OR}=$ odds ratio; $\mathrm{Cl}=$ confidence interval.

*Evaluation performed according to the criteria of Joanna Briggs Institute Prevalence Critical Appraisal Tool. 
to several factors, as well as to distinct ethnicities among the populations evaluated. Among the studies analyzed, three were carried out in African countries, one in an Asian country and the others in Brazil, a Latin country characterized by a great ethnic diversity associated with immigration. The variation in the sample number of the studies can also be attributed to the ability to detect distinct genetic alterations among the surveys.

On the same question of ethnicity, the findings of Lidani et al..$^{17}$ and Martins et al. ${ }^{12}$ demonstrated a higher prevalence of sickle cell trait among afrodescendant individuals. Global epidemiological data indicate that the disorders associated with $\mathrm{HbS}$ are heterogeneously distributed. According to the World Health Organization, in 2006, between 10 and $40 \%$ of the children of Equatorial Africa were born with sickle cell trait. Among African countries, Nigeria and Ghana have the highest prevalence. In the United States of America (USA), a survey conducted by the National Newborn Screening Information System, between 2005 and 2007, showed that the prevalence of disorders associated to $\mathrm{HbS}$ is greater among afro-descendant individuals (1:365 and 1:601, respectively) than among Hispanics (1:16,305 and 1:18,642, respectively). These data confirm that the prevalence of hemoglobinopathies related to $\mathrm{HbS}$ is strongly associated with ethnicity.

The detection methods of $\mathrm{HbS}$ are varied and differ between qualitative and quantitative tests. ${ }^{20}$ The hemoglobin electrophoresis test was used for all the selected studies, allowing the identification of different types of hemoglobin based on their differences in electrophoretic mobility in an electric field generated by electrodes.,12-18 The studies of Martins et al. ${ }^{12}$, Alabdulaali et al. ${ }^{14}$ and Lidani et al. ${ }^{17}$ evaluated solubility concomitantly with hemoglobin electrophoresis. The solubility test has the principle of reducing $\mathrm{HbS}$, and, due to insoluble characteristics of the inorganic buffer, forms deoxi-HbS polymers with the reagent. ${ }^{20}$ However, studies comparing different methods of screening for hemoglobinopathies demonstrate that the use of solubility method for the detection of $\mathrm{HbS}$, which is widely practiced because of its low cost and ease of performance, has limitations that may generate false-negative and false positives. ${ }^{6}$ The sickling was the additional test adopted in studies of Martins et al. ${ }^{12}$, Vivas et al. ${ }^{13}$ and Antwi-Baffour et al. ${ }^{7}$ This is a qualitative assessment that only detects the presence of HbS without identifying other hemoglobin variants. ${ }^{21}$
Only the study of Vivas et al..$^{13}$ used the quantitative technique of high performance liquid chromatography (HPLC), which was adopted both as a confirmatory test and for the determination of the values of the fractions of hemoglobin, after the detection of HbS by the previously mentioned tests. It is worth mentioning, however, that all the studies suggest its use in cases of doubtful detection of $\mathrm{HbS}$, not differentiated by the tests mentioned above.,12-18

It is important to highlight that blood from donors with $\mathrm{HbS}$ suffers polymerization when stored. Even so, the same need not be discarded, since its use does not entail complications to recipients in need of restoration of the levels of erythrocytes. However, it should be labeled and duly identified as $\mathrm{HbS}$ positive ${ }^{9,22}$. In the case of patients with hemoglobinopathies, with severe acidosis or who use equipment for mechanical ventilation, exposure to concentrated red blood cells containing $\mathrm{HbS}$ can cause a worsening of their condition, since these individuals have a tendency to hemolysis. In intrauterine transfusions or in newborns, aggravation occurs due to physiological immaturity and, consequently, the inability to metabolize hemolysis products, generating an increase in the probability of vase-occlusion and organ lesions associated with the proportionately lower presence of veins and capillaries. ${ }^{23}$

In addition to possessing great clinical significance for the proper use of the blood components, positive findings in screening tests for $\mathrm{HbS}$ in blood donors can also be used for raising awareness and genetic counseling ${ }^{21}$, within ethical boundaries and respecting the right of reproduction of these individuals. ${ }^{23}$ None of the selected studies addressed the occurrence of notification. However, even if this was not reported, the majority of studies point out the importance of the deployment of a team for effective implementation of genetic counseling with the aim of preventing future cases of sickle cell anemia, homozygous manifestations and more severe manifestations of the disease.,12-18

As a positive point, this SRL is characterized by the independent searches of articles and evaluation of their methodological quality by two authors, increasing the likelihood of identifying and including all publications related to the topic and the performance of an assessment of reliable quality. Furthermore, the search was quite comprehensive, since restrictions on languages or the place of execution of the survey were not applied. Moreover, the development of the study gave 


\section{Original article}

correct routing of the guideline PRISMA ${ }^{10}$ systematic reviews and meta-analyzes and the evaluation of methodological quality was performed with the use of the Joanna Briggs Institute Prevalence Critical Appraisal Tool, which assists in the interpretation of the results of cross-sectional studies and thereby broadens the analysis of the studies evaluated.

However, some limitations should be taken into consideration. Although the search was comprehensive, many articles were discarded because they did not fit the eligibility criteria. For this reason, some publications may not have been included in this review. And, since this review is based on published data, it is possible that publication bias decreases the representativeness of our results.

The prevalence of sickle cell trait among blood donors is highly variable, but cannot be subdued, since the use of blood containing $\mathrm{HbS}$ is subject to limitations. Thus, screening for $\mathrm{HbS}$ among blood donors should be incorporated in hemotherapy services. This would allow for the appropriate use of blood components, thus promoting transfusion safety, but could also reduce the prevalence of anemia by means of notification to positive donors.

\section{Conflicts of interest}

The authors declare that they have no conflicts of interest.

\section{References}

Rees DC, Williams TN, Gladwin MT. Sickle-cell disease. Lancet 2010;376:2018-31

2. Odièvre MH, Verger E, Silva-Pinto AC, et al. Pathophysiological insights in sickle cell disease. IJMR. 2011;134:532-7.

3. Adekile AD. What's new in the pathophysiology of sickle cell disease? MPP. 2013;22:311-2.

4. Lei H, Karniadakis GE. Quantifying the rheological and hemodynamic characteristics of sickle cell anemia. Biophys J 2012;102:185-94

5. Murao M, Ferraz MHC. Traço falciforme - heterozigose para hemoglobina S. Rev Bras Hematol Hemoter. 2007;29:223-5.

6. Silva JEP. Traço falciforme: Uma visão para os Centros de Hemoterapia. Revista Saúde. 2010;36:23-8.

7. /Antwi-Baffour S, /Asare RO, Adjei JK, et al. Prevalence of hemoglobin S trait among blood donors: a cross-sectional study. BMC research notes. 2015:8:583
8. Ministério da Saúde, B. RDC No 57, de 16 de dezembro de 2010. Available in: http://mun2, ebserh, gov.br/documents/147715/O/RDC+n+57-2010+Regulamento+Sanit\%C3\%A1 rio.pdf/b4a906a4-3763-482a-b1 af-9dfc9ff2e411. Accessed in: 01/2019

9. Ministério da Saúde, B. Portaria No 158, de 04 de fevereiro de 2016. Available in: https://cevs.rs.gov.br/upload/arquivos/201612/16112320-portaria-158-de-04-02-2016.pdf Accessed in: 01/2019

10. Moher D, Liberati A, Tetzlaff J, et al. Systematic Reviews and Meta-Analyses: The PRISMA Statement. Ann Intern Med 2009;151:264-9.

1. Moher D, Liberati A, Tetzlaff J, et al. Preferred reporting items for systematic reviews and meta-analyses: the PRISMA state ment. J Clin Epidemiol. 2009;62:1006-12.

12. Martins PRJ, Pereira GDA, Pacheco KD, et al. Avaliação da freqüência de Hemoglobina A1s nos candidatos à doação de sangue no Hemocentro regional de Uberaba, no período de 1996 a 2000 - Estudo retrospectivo. Rev Med Minas Gerais 2005:15:34-7.

13. Vivas W, Rebouças D, Fabbro A, et al. Heterozigose para hemoglobinopatias em doadores de sangue do Centro de Hemoterapia de Sergipe. Rev bras hematol hemoter. 2006:28:284-7

14. Alabdulaali MK, Alayed KM, Alshaikh AF, et al. Prevalence of glucose-6-phosphate dehydrogenase deficiency and sickle cell trait among blood donors in Riyadh. AJTS. 2010;4:31.

15. Moraes KCM, Galioti JB. A doença falciforme: um estudo genético-populacional a partir de doadores de sangue em São José dos Campos, São Paulo, Brasil. Rev Bras Hematol Hemoter. 2010;32:286-90.

16. Egesie OJ, Egesie UG, Jatau ED, et al. Prevalence of sicke cell trait and glucose 6 phosphate dehydrogenase deficiency among blood donors in a Nigerian tertiary hospital. Afr $J$ of Biomed Res. 2013;16:143-8.

17. Lidani KCF, Barros RF, Bovo F. Relationship between the prevalence of hemoglobin $S$ and the ethnic background of blood donors in Paraná state. JBPML. 2015;51:212-7.

18. Adu P, Simpong DL, Takyi G, et al. Glucose-6-phosphate dehydrogenase deficiency and sicke cell trait among prospective blood donors: A cross-sectional study in Berekum, Ghana. Adv Hematol. 2016:1:1-7

19. Bastos JLD, Duquia RP. Erratum para: Um dos delineamentos mais empregados em epidemiologia: Estudo transversal. Sci Med. 2013:23:229-32.

20. Grilo KTM, Pasqualin MAJ, Barbosa VL. HEMOTERAPIA: Artigos científicos de conclusão de curso de pós-graduação lato sensu em Hemoterapia. Curitiba: SESA: SETI/NEM, 2015

21. Prudêncio BCAB, Covas DT, Bonini-domingos CR. Comparação de metodologia utilizada para a detecção de Hemoglobina $\mathrm{S}(\mathrm{HbS})$ em doadores de sangue. Rev Bras Hematol Hemoter 2000;22:99-109

22. Ministério da Saúde, B. RDC No 153, de junho de 2004 Available in: http://mun.sbpc.org. br/upload/noticias_ gerais/320100416113458.pdf. Accessed in: 01/2019

23. Roseff SD, Bethesda MD. American Association Blood Banks.

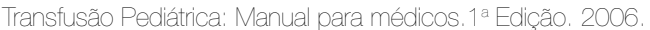

